PAEDAGOGIA ChristianA

$1 / 23(2009)$ - ISSN 1505-6872

Barbara Surma*

Kraków

\title{
Formacja religijna dziecka a rola dorosłego w koncepcji pedagogicznej Marii Montessori na przykładzie „Katechezy Dobrego Pasterza” Sofii Cavalletti
}

Celem wychowania dziecka w systemie pedagogicznym Marii Montessori (1870-1952) jest wspieranie jego wszechstronnego rozwoju. Istotną rolę w koncepcji pedagogicznej M. Montessori odgrywa całościowa formacja osoby dziecka, w tym również formacja religijna. M. Montessori, tworząc system pedagogiczny, już w roku 1915 poczyniła pierwsze doświadczenia w zakresie wychowania religijnego małego dziecka opartego na wyznaniu katolickim. Jednak dziedzinę tę rozwinęły dopiero po roku 1954 dwie Włoszki: Sofia Cavalletti i Gianna Gobbi ${ }^{1}$. Obecnie metoda i program formacji religijnej La Catechesi del Buon Pastore, czyli „Katecheza Dobrego Pasterza”, znana jest w wielu państwach na całym świecie, również w Polsce ${ }^{2}$. W wielu placówkach wychowania przedszkolnego prowadzonego w systemie pedagogicznym M. Montessori oraz w innych, zwanych „tradycyjnymi”, realizuje się treści zaproponowane przez „Katechezę Dobrego Pasterza" dzięki opracowaniu wybranych tematów w podręczniku Wędrowanie z Bogiem. Podręcznik metodyczny do religii dla klasy $0^{3}$.

* Dr Barbara Surma, adiunkt na Wydziale Pedagogicznym Wyższej Szkoły Filozoficzno-Pedagogicznej „Ignatianum” w Krakowie.

${ }^{1}$ Zob. S. Cavalletti, Potencjat duchowy dziecka. Doświadczenia z dziećmi w wieku od 3 do 6 lat, thum. K. Stopa, Kraków 2001; taż, Potencjat duchowy dziecka w wieku od 6 do 12 lat. Opis doświadczenia, tłum. K. Stopa, Kraków 2003.

${ }^{2}$ Zob. B. Surma, Pedagogika Montessori-podstawy teoretyczne i twórcze inspiracje w praktyce, Łódź 2008.

${ }^{3}$ T. Czarnecka, Wł. Kubik SJ (red.), Wędrowanie z Bogiem. Podręcznik metodyczny do religii dla klasy 0, Kraków 2003. 
Celem tego artykułu jest krótkie przedstawienie idei „Katechezy Dobrego Pasterza"4 opartej między innymi na koncepcji pedagogicznej M. Montessori, w której centralne miejsce zajmuje dziecko, wskazujące dorosłemu właściwą drogę własnego rozwoju, w tym rozwoju duchowego.

W pierwszym punkcie omawiam podstawy Katechezy, której głównym przesłaniem biblijnym jest głoszenie ,przymierza” zawartego przez Boga z człowiekiem, jako znaku Miłości. W drugim punkcie przybliżam wytyczne Kościoła dotyczące roli katechezy i katechety oraz przedstawiam poglądy S. Cavalletti na ten temat. W ostatnim punkcie opisuję metodę pracy katechetycznej, opracowaną przez S. Cavalletti, zwaną metodą znaku.

\section{Formacja religijna dziecka}

Zdaniem S. Cavalletti, formacja religijna dziecka polega na udzielaniu mu pomocy w nawiązywaniu i ustalaniu relacji z Bogiem, które w języku biblijnym nazywane jest „przymierzem”. Takie ujęcie wypływa z rozumienia życia religijnego w ogóle, bowiem życie religijne jest relacją z Bogiem, w Bogu i z braćmi. Na takiej relacji buduje się także życie moralne osoby, które polega przede wszystkim na „byciu”.

Wczesne dzieciństwo, co podkreśla bardzo mocno S. Cavalletti, jest okresem, kiedy osoba ze wszystkimi zdolnościami duszy, serca i ducha kształtuje się. Dlatego formacja religijna w tym okresie powinna służyć Życiu na najgłębszym poziomie „bycia” (włoskie essere znaczy „być”), a nie „działania” (włoskie fare oznacza „robić, czynić”). Jeżeli osoba dorosła pomoże dziecku w ustabilizowaniu relacji z Bogiem i z ludźmi, czyli pozwoli mu „być”, to w późniejszym czasie ono samo będzie szukało wskazówek dotyczących tego, co ma robić, jakie zachowania i postawy ma wybierać 7 .

Sofia Cavalletti uważa, że formacja religijna ma dotyczyć osoby dziecka takiego, jakim jest, jego spontanicznej religijności, pragnienia Boga - prawdziwej Miłości, objawionej w Osobie Chrystusa. A zatem formacja religijna ma polegać na wspólnym - dziecka i dorosłego - podążaniu w kierunku poznania Boga. Katecheza powinna zaspokajać podstawowe potrzeby duchowe dziecka, w tym potrzebę nawiązania relacji z Bogiem, który jest Miłością. Podobnie jak zaspokajanie innych potrzeb, takich jak bezpieczeństwa, miłości, akceptacji, prowadzi

${ }^{4}$ Zob. B. Surma, Katecheza Dobrego Pasterza, „Homo Dei” 3 (1999), s. 39-50.

${ }^{5}$ Por. S. Cavalletti, God in search of the child. The young child as a partner in the Covenant. Cyt. za: Lee Nam Mi, L'Educazione religiosa del bambino secondo Maria Montessori oggi. La „Catechesi del buon Pastore” per i bambini da tre a sei anni, Tesi per la Licenza, Rzym 2000-2001, s. 114.

${ }^{6}$ Por. S. Cavalletti, Formazione religiosa e fanciullezza, „Vita dell'infanzia” 12 (1979), s. 7.

${ }^{7}$ Por. taż, La ricchezza dell'esperienza religiosa precoce, „Vita dell'infanzia” 19 (1983), s. 10; taż, La formazione religiosa del bambino, „Vita dell'infanzia” 6 (1994), s. 47. 
do harmonijnego rozwoju psychofizycznego dziecka, tak zaspokajanie potrzeb duchowych prowadzi do prawidłowego rozwoju duchowego. Zdaniem S. Cavalletti, dziecko wskazuje na te potrzeby swoim zachowaniem poprzez głębokie zainteresowanie przedmiotami, melodią zdania, słowami związanymi z życiem religijnym. Dziecko podąża za pewnego rodzaju wewnętrznymi, życiowymi bodźcami, które wymagają od niego zdobycia określonej umiejętności. W przypadku zaspokojenia tego typu potrzeb, dziecko ma poczucie radości i pokoju, co w konsekwencji pomaga mu w nawiązywaniu pozytywnych kontaktów z innymi ludźmi. Natomiast niezaspokojenie ich sprawia, że „wygasa żywotna siła i pojawiają się wypaczenia, które mogą wywrzeć wpływ na całe jego życie"8.

Koncepcja wychowania religijnego tej autorki opiera się na teologii biblijnej, wypływającej z tradycji judeochrześcijańskiej, której celem jest nawiązanie relacji - „przymierza”. Sofia Cavalletti wyjaśnia, że przymierze pokoju: „berit jest uniwersalną harmonią, która pochodzi od jedynego Osobowego Boga, Pana historii a celem tego przymierza jest zjednoczenie wszystkich poziomów stworzenia". Częściowo dokonuje się to podczas Eucharystii, kiedy Chrystus jednoczy nas z Bogiem w komunii dzięki owocom naszej pracy i darom stworzonym przez Boga Ojca. Czytając Biblię, dostrzegamy, że przedstawia nam ona tę rzeczywistość, wychowuje nas do zrozumienia i przyjęcia tej jedności, wskazując np. obraz Boga - małżonka „bo małżonkiem twoim jest twój Stworzyciel, któremu na imię - Pan Zastępów" (Iz 54, 5). Innym obrazem Boga w Starym Testamencie jest „pasterz”, który strzeże i chroni swój naród, w Nowym Testamencie tym pasterzem jest sam Jezus, który wołając każdego po imieniu buduje relację: osobistą i wspólnotową.

Zdaniem S. Cavalletti, wychowanie do „berit” oznacza sianie „ziaren pokoju". Ponadto

wychowanie do „berit” oznacza wychowanie do wyjścia poza siebie, do otwarcia się na szukanie Kogoś i innych. Jest to uczenie otwierania okien i drzwi, a przede wszystkim serca, aby patrzeć i słuchać Kogoś i innych. Wychowywać do przymierza oznacza prowadzić formację religijną i moralną, dzięki której poznaje się „Boga, który szuka człowieka" (według wyrażenia Abrahama Jeshua Heschel), Boga który chce zawrzeć przymierze, w którym On sam jest Partnerem. Wychowanie to ma uświadamiać dziecku, że na świecie są inni, których musi poznać, których musi szanować, od których może zawsze się uczyć i, że nie musi z nimi wygrywać (walczyć, pokonywać, zdobywać) za wszelką cenę nawet wtedy, gdy posiada do tego odpowiednie środki ${ }^{10}$.

Dziecko od najwcześniejszych swoich dni żyje w relacji z najbliższymi i uczy się relacji ze światem. Jest to podstawą jego rozwoju psychofizycznego.

\footnotetext{
${ }^{8}$ Taż, Potencjal duchowy dziecka, s. 221.

${ }^{9}$ Taż, Semi di pace, „Vita dell'infanzia” 12 (1971), s. 8.

${ }^{10}$ Tamże, s. 8.
} 
Podobnie dzieje się na płaszczyźnie duchowej. Religijność dziecka wypływa z jego naturalnej potrzeby i opiera się na nawiązywaniu relacji z Bogiem.

\section{Rola katechety}

Zadaniem nauczyciela-katechety, które wynika z nauki o katechezie ${ }^{11}$, jest przygotowanie i umożliwienie spotkania swojemu uczniowi z Mistrzem. Jan Paweł II wyjaśnia, że istotą katechezy jest „,spotkanie w wierze tych, którzy nauczają i tych, którzy bywają nauczani"12, a zatem zakłada pewną relację, której podstawy znajdują się w samym znaczeniu słowa „katecheo"13. Katecheza często przybiera charakter ewangelizacji, której celem jest głoszenie Dobrej Nowiny, czyli posługi Słowa. Katecheta, zdaniem Zbigniewa Marka, nie może być tylko nauczycielem, którego roląjest przekazywanie pewnego zakresu wiedzy i kształtowanie osobowości ucznia, ma być świadkiem wiary, ale i współtowarzyszem na drodze wiary ${ }^{14}$. Warto podkreślić, co odnotowuje Z. Marek, że katecheci często „chcieliby swoich wychowanków ustrzec przed zbyt silnymi wstrząsami i zranieniami w wewnętrznym zmaganiu się ze sobą. W tym celu odwołują się do własnych doświadczeń i sugerują katechizowanym możliwości skrócenia drogi, na której muszą zmagać się z występującymi trudnościami. Tymczasem nieporozumienie polega na tym, że katecheta zapomina, iż wobec katechizowanego pełni inną od nauczyciela funkcję - funkcję partnera, towarzysza wspólnej drogi" ${ }^{15}$. Można tu przypomnieć i porównać słowa Marii Montessori, dotyczące rozwoju fizycznego i intelektualnego dziecka. Twierdziła, że nie można rosnąć za dziecko, można tylko wspomagać jego własny rozwój. Słowa te można zastosować do rozwoju duchowego, a zatem i do roli katechety.

Sofia Cavalletti łączy zadanie nauczyciela ze słowem nauczać - ,insegnare”, co po włosku oznacza ,wskazywać-znaczyć” punkt. A zatem nauczyciel powinien swoim uczniom wskazywać na ile to możliwe cel, prawdę, ale nic ponad to ${ }^{16}$. Katecheta musi być obiektywny w tym, czego naucza, gdyż przedmiotem jego nauki jest prawda. Aby stała się ona, jak pisze S. Cavalletti, „materią organiczną ducha, uczeń musi ją sam przyjąć, poznać, uczynić własną" ${ }^{17}$. Kiedy autorka ta pisze, że dziecko ma samo dochodzić do prawdy, chodzi jej o pozosta-

${ }^{11}$ Por. Dyrektorium ogólne o katechizacji, Poznań 1998; oraz Dyrektorium Katechetyczne Kościoła Katolickiego w Polsce, Kraków 2001.

${ }_{12}$ Jan Paweł II, Wierzę w Boga Ojca Stworzyciela, Città del Vaticano 1987, s. 13.

${ }^{13}$ Por. Dyrektorium Katechetyczne Kościoła Katolickiego w Polsce, s. 26; Por. także Z. Marek, Biblia w katechetycznej postudze Słowa, Kraków 1998, s. 15.

${ }^{14}$ Por. tamże, s. 17.

15 Tamże, s. 16.

${ }^{16}$ S. Cavalletti, Formazione religiosa del fanciullo, Opera unità riparatrice, z. 2: Educazione religiosa del fanciullo, cz. 5, s. 12.

${ }^{17}$ Tamże, s. 12. 
wienie dziecku możliwości ciszy, zatrzymania się na przedmiocie, treści, by pod delikatnym przewodnictwem Tego, który przemawia w ciszy duszy, mogła się dokonać wewnętrzna rozmowa. S. Cavalletti zwraca uwagę, że między katechetą a przedmiotem jego nauczania istnieje rozbieżność: „katecheta jest istotą ludzką, a przedmiotem jego nauczania jest prawda. Most między tymi dwoma elementami jest utworzony przez wewnętrznego Mistrza, który jednak przemawia w ciszy i w skupieniu. Ale jeśli zawsze mówię ja, nie daję Jemu możliwości, by mógł przemówić"18.

Nauczyciel musi wierzyć w możliwości dziecka w dochodzeniu do prawd wiary i nie może go wyręczać. Rolą dorosłego jest stwarzanie warunków do tego, aby dziecko samodzielnie mogło je odkrywać, a także by mogło nawiązywać relację z Bogiem. S. Cavalletti wręcz domaga się od katechety czujności, aby swoją zbyt natarczywą postawą nie zaburzył tego, co zaczyna się rozwijać. Pomoca, jaką może nieść w tym przypadku, jest proponowanie narzędzi, dzięki którym dziecko może poznawać Słowo Boże, medytować i rozważać je w swoim wnętrzu. Zdaniem S. Cavalletti, nauczyciel powinien umieć mówić jak najmniej i uszanować ciszę. Nauczyciel, nie tylko według S. Cavalletti, ale również M. Montessori, powinien umieć traktować poważnie dziecko, szanować je, gdyż każdy posiada swoją godność, która jest wpisana w naturę. Dorosły w metodzie M. Montessori powinien pomagać dziecku, ale w sposób bardzo dyskretny i na ile to możliwe w sposób pośredni wpływać na jego aktywność.

Bóg jest tym, który prowadzi dziecko w jego formowaniu i rozwijaniu się w sposób szczególny. Stwórca i stworzenie, Bóg, który daje życie, i człowiek, który je otrzymuje i żyje, wielbiąc Boga. Myśl ta jest podstawą budowania i wyrażania przez osobę dorosłą szacunku do dziecka. Respekt ten ma wybitnie charakter religijny ${ }^{19}$.

Katecheta musi mieć na uwadze, że stanowi łącze pomiędzy tymi dwoma wielkimi bohaterami katechezy. A zatem, jaka jest jego pozycja w tym dziele? S. Cavalletti uważa, że ,nauczyciel nie musi, dlatego że nie może, nadać kształtu dziecku, ale może i musi pomóc mu przyjąć taki kształt, jaki Bóg wybrał dla niego. Człowiek nie może nic stworzyć na poziomie fizycznym, a jeszcze mniej na poziomie psychicznym i duchowym; ale skoro może służyć siłom natury na poziomie fizycznym, tak samo może czynić na polu psychicznym i duchowym, może służyć siłom duchowym. I to jest to, co musi robić nauczyciel"20.

Rolą katechety, mówiąc słowami Biblii, jest być „sługą nieużytecznym” Ewangelii. „Na początku było Słowo”, a nie doświadczenie dorosłego. Słuchanie Słowa jest tym, co ma robić dorosły, by prowadzić dziecko ${ }^{21}$. Przypowieść o za-

${ }^{18}$ Tamże, s. 12.

${ }^{19}$ Tamże, s. 13.

${ }^{20}$ Tamże, s. 13.

${ }^{21}$ Por. S. Cavalletti, G. Gobbi, Io sono il buon Pastore, sussidi per la catechesi dei bambini, I anno, guida per il catechista, Rzym 1970, s. 8. 
siewie wskazuje na rolę, jaką ma do spełnienia człowiek dorosły. Musi zasiać, ale reszta nie zależy od niego. Jeżeli będzie mu dane zobaczyć kłos, będzie mógł powiedzieć, że Bóg jest tym, który pozwolił temu ziarnu dojrzećéc. Takie podejście jednak nie umniejsza roli siewcy. Katecheta powołany jest do siania ziarna prawdy. Zdaniem S. Cavalletti, ,funkcja pośredniczenia, jaką pełni dorosły, jest konieczna w ewangelizacji, niemniej jednak nie należy jej przeceniać. Katecheta głosi Słowo, które nie jest jego, a zarazem pomaga dziecku, by rozwinęły się w nim pewne możliwości, które również w żaden sposób do niego [katechety] nie należą"23.

Tego, czego wielokrotnie można doświadczać w czasie pracy katechetycznej, a co zdumiewa, często nie można nazwać efektem pracy dorosłego. S. Cavalletti zauważa że: „[Katecheta] Nie może nie zdawać sobie sprawy z dysproporcji między tym, co dał, a tym, co dzieci posiadają i czym żyją. [...] Istnieje tajemnicza więź łącząca Boga z dzieckiem, [...] więź, której nie da się wytłumaczyć efektem ludzkiej pracy"'24. Jest to namacalna więź, jaka tworzy się między Bogiem i dzieckiem, a zadaniem katechety jest stworzyć ku temu odpowiednie warunki. Powinien on pamiętać, że ,jego pośrednictwo jest służbą, jaką ofiaruje on Bożemu Słowu oraz dziecku”25. Jeżeli „katecheta, nie umie zatrzymać się i nie potrafi milczeć, nie jest świadom swoich ograniczeń i ostatecznie nie ma wystarczającej wiary, gdyż - przynajmniej na płaszczyźnie praktycznej - nie jest przekonany, że tym, który działa w rzeczywistości religijnej jest Bóg i Jego Słowo stwórcze"26, nie spełni właściwie swego zadania w wychowaniu religijnym dziecka.

Przedstawione powyżej poglądy są bardzo zbieżne $\mathrm{z}$ nauczaniem Jana Pawła II, który pisze:

Każdy katecheta, niezależnie od zajmowanego w Kościele stanowiska, musi troszczyć się usilnie, aby poprzez swoje nauczanie i swój sposób życia przekazywać naukę i życie Chrystusa. Niech nie zatrzymuje na sobie samym, na swoich osobistych poglądach i własnych postawach myślowych ani uwagi, ani przywiązania umysłu i serca tego, kogo katechizuje, a zwłaszcza niech nie wpaja innym swych własnych opinii i zapatrywań w taki sposób, jak gdyby wyrażały one naukę Chrystusa i świadectwo Jego życia. Trzeba więc, aby do każdego katechety można było zastosować te niezgłębione słowa Jezusa: „Moja nauka nie jest moja, ale Tego, który Mnie posłał" $(\mathrm{J} 7,16)^{27}$.

Sofia Cavalletti uważa, że dziecko należy traktować jako istotę o wewnętrznym bogactwie, a nauczyciel może wskazywać jedynie Osobę Jezusa i Jego na-

${ }^{22}$ Zob. S. Cavalletti, G. Gobbi, Educazione religiosa, liturgia e metodo Montessori, Rzym 1961, s. 29.

${ }^{23}$ S. Cavalletti, Potencjat duchowy dziecka, s. 63.

${ }^{24}$ Tamże, s. 63.

${ }^{25}$ Tamże, s. 63.

${ }^{26}$ Tamże, s. 63.

${ }^{27}$ Jan Paweł II, Catechesi tradendae, nr 6. 
ukę jako wzór do naśladowania. Jednakże wskazując dziecku Jezusa również katecheta powinien brać z Niego przykład. Jezus jako Jedyny Nauczyciel i Mistrz wskazuje dorosłemu, w jaki sposób ma nauczać. Chrystus, znając możliwości percepcyjne ludzi, głosił Dobrą Nowinę za pośrednictwem przypowieści, czyli opierał się na metodzie, która można nazwać „metodą znaku”.

\section{Metoda znaków}

„Katecheza Dobrego Pasterza” jest katechezą, czyli spotkaniem z Bogiem zarówno osób katechizowanych, jak i katechizujących. S. Cavalletti tłumaczy, że „katecheza nie jest tylko jednym z wielu przedmiotów, których uczy się dziecko: katecheza to wspólne słuchanie i wspólna celebracja Słowa, w którym jest tylko jeden Nauczyciel i z całą pewnością to nie my nim jesteśmy. Jeśli mamy przed sobą dwadzieścioro dzieci, wówczas jest dwudziestu jeden słuchaczy"28.

Oczywiście, katecheza rozumiana jako metoda powinna zaopatrzyć wszystkich uczestników w niezbędne narzędzia do odczytywania myśli i Bożego działania. Tym narzędziem jest wybór odpowiedniej metody zgodnej z tym, co jest przekazywane. A przekazywana jest Tajemnica Boga, którego nie da się zdefiniować. Bóg jest nieskończony i do końca niepoznawalny, dlatego wychowanie religijne powinno czerpać ze źródeł biblijnych i liturgicznych, które posługują się językiem znaków, a nie definicji.

Sofia Cavalletti zauważa, że „Liturgia zawsze przemawiała za pośrednictwem znaków, a Jezus „,bez przypowieści nie przemawiał do nich” (Mk 4, 33)”29. Język, dzięki któremu człowiek może się zbliżyć do Boga, „nie może być innym językiem jak aluzyjnym, złożonym oczywiście ze „znaków”, to znaczy z konkretnych elementów - widzialnych, dotykalnych, a także słyszalnych - które odsyłają do zawartości, która sama z siebie jest poznawana przez zmysły" ${ }^{30}$. Jej zdaniem, między znakiem a jego zawartością istnieje więź na poziomie istnienia - bycia, ponieważ samo znaczenie znaku niesie w obfitości to, co w sobie zawiera, nawet jeśli „pojemnik jest mniejszy od zawartości”’31. Przykładem tego może być drogocenna perła i inne obrazy w przypowieściach, które pozwalają się nam zbliżyć do tajemnicy królestwa Bożego, same w sobie są proste, pokazują to, co najważniejsze, ale nie wyczerpują tematu o wskazywanej przez siebie rzeczywistości, zawsze można powiedzieć i odkryć coś więcej.

Dzięki znakom liturgicznym można nie tylko słuchać opowiadań o działaniu Boga dla człowieka, ale i współuczestniczyć w historii zbawienia. Natomiast

${ }^{28}$ S. Cavalletti, Characteristics of the Good Shepherd Catechesis, ,Journals of the Catechesis of the Good Shepherd" 1984-1997, s. 25.

${ }^{29}$ Taż, Potencjat duchowy dziecka, s. 204.

${ }^{30}$ Taż, A B C del cristianesimo (tekst niepublikowany), Rzym 1997, s. 2.

${ }^{31}$ Tamże, s. 2. 
słuchanie i rozważanie Słowa Bożego jest słuchaniem samego Boga, który „tu i teraz” przemawia, daje się poznać człowiekowi, gdyż „w danym wydarzeniu religijnym Bóg jest czynnie obecny wraz ze swym Słowem"32.

Biblia i Liturgia pokazuja, jak rozległy jest język znaków, których umiejętność odczytywania jest zadaniem człowieka wierzącego. Charakter znaków wyznacza pewną metodologię, która powinna mieć charakter tego, co można nazwać abecadłem chrześcijaństwa. Ucząc, trzeba pamiętać, że nie można przekazać wszystkich odcieni czy dźwięków danego języka. Nie można wyprzedzić, czy nawet ominąć pewnych etapów podczas zdobywania umiejętności czytania. Najpierw trzeba poznać abc, by następnie móc zgłębiać różnorodne teksty. Formacja religijna powinna opierać się na podobnych zasadach. Przekazując treść [Dobrą Nowinę], należy czynić to w sposób jak najbardziej obiektywny, w pierwszym kontakcie posługując się tylko niezbędnymi słowami. To zasiane ziarno [Dobra Nowina] ma w sobie wartość, to ono ma kiełkować i rozwijać się tak, aby stawało się esencją życia religijnego osoby nauczanej i uczącej.

Problem posługiwania się językiem znaków w wychowaniu religijnym oraz adresat, jakim jest dziecko, zwłaszcza przed ukończeniem szóstego roku życia, narzuca również określony sposób pracy. Jest on odmienny od tego, który wypracowała teologia. S. Cavalletti stwierdza: „opracowanie teologiczne przedstawia odmienny sposób przekazywania „nowiny” niż abc; jest to inny język, który zakłada proces umysłowy ze strony tego, który słucha"33.

Sofia Cavalletti zauważa pewne niebezpieczeństwo w sposobie katechizacji, która już od czasów wczesnego średniowiecza stawała się przekazywaniem tez już rozwiązanych i głoszonych w formie syntetycznej (wiązało się to z rozwojem teologii, która przyjęła kierunek metodologiczny o charakterze abstrakcyjnym $\mathrm{i}$ intelektualistycznym ${ }^{34}$ ). Skutkiem tak pojętego nauczania, zdaniem S. Cavalletti, było to, iż: „katechizowanemu nie pozostawało nic innego, jak tylko przyjmowanie ich [tez, wiadomości] w takim wypracowanym już kształcie bez żadnego zaangażowania na płaszczyźnie osobistej z wyjątkiem pamięciowego opanowania nauczanych treści"35. Takie podejście kłóci się z istotą procesu nauczania, który składa się z dwóch momentów, których nie można pominąć. Pierwszy to jest głoszenie-słuchanie, drugi to osobiste przyjmowanie, przetwarzanie, medytacja, czyli osobiste spotkanie z Bogiem. S. Cavalletti nazywa ten drugi moment, powołując się na św. Augustyna, rozmową z wewnętrznym Mistrzem. Dla podkreślenia ważności tego etapu pisze, że jest to: „moment niezwykle żywy w procesie uczenia się, jest to moment, w którym to, co umysł uchwycił, powoli zagłębia się w człowieka, powoli zmienia się w śmiałe wyrażenie, „ciało i krew” swojego ducha. Bez tego drugiego momentu pierwszy byłby okaleczony, nie-

${ }^{32}$ M. Searle, Przedmowa, w: S. Cavalletti, Potencjat duchowy dziecka, s. 11.

${ }^{33}$ S. Cavalletti, A B C del cristianesimo, s. 3.

${ }^{34}$ Por. taż, Potencjat duchowy dziecka, s. 201.

${ }^{35}$ Tamże, s. 202. 
kompletny, ponieważ pozostałoby to wszystko na poziomie powierzchowności, nauka pozostałaby na zewnątrz osoby, zajęłaby intelekt, a przecież człowiek nie składa się tylko z intelektu. Brakowałoby osobistej pracy, która jest jedynym narzędziem, środkiem, który pomaga w zdobywaniu prawdziwie głębokich umiejętności”’36.

Liturgia i Biblia ofiarują nam w obfitości wszystko to, co jest potrzebne dla katechezy, katecheta może znaleźć właśnie tam największe i najważniejsze tematy orędzia chrześcijańskiego. Metoda znaku ma charakter religijny, ponieważ jest „świadoma swych ograniczeń, a zatem pełna czci wobec Tajemnicy, o której wie, że jest niezgłębiona, której nie zamierza wyjaśnić, opisać, zdefiniować"37, lecz stara się przybliżyć, posługując się językiem aluzyjnym. Znak pozostawia miejsce na osobisty wysiłek każdego człowieka, a sposób jego odbioru będzie zależał od odbiorcy w granicach wyznaczonych przez znak. Fakt ten powinien działać wychowawczo na katechetę, uczyć pokory zarówno jego, jak i katechizowanego. Metoda znaku wytycza również szlak w poszukiwaniu i doborze treści. Zdaniem S. Cavalletti, „dobry katecheta to taki, który eksponuje tylko to, co znajduje w liturgii i w Piśmie świętym"38.

Wprowadzanie w liturgię musi opierać się na znakach, które przedstawione i pozostawione dzieciom przemawiają do nich własnym językiem. Istotne jednak wydaje się rozpoczęcie tego procesu od przedstawiania przypowieści i nauki czytania wszystkich tekstów biblijnych na poziomie opisowym i symbolicznym. Chcąc przedstawić dziecku teksty biblijne, należy z wielką rozwagą dokonać ich wyboru, tak aby dziecko mogło pojać ich treść teologiczną. „Biblia jest księga teologii historycznej lub historii teologicznej. Teologii nie można odseparować od historii, gdyż w przeciwnym razie sprzeniewierzylibyśmy się jej przesłaniu" ${ }^{39}$. Dlatego S. Cavalletti przestrzega przed czytaniem tekstów, które opisują „,historię", którą dziecko może z łatwością uchwycić, ale nie pojmie w niej teologii. Tekst Biblii stanie się dla dziecka „historyjką”. Autorka ta twierdzi z przekonaniem, że „wydarzenie przyswojone tylko jako „historia” pozostanie taką również wówczas, gdy dziecko urośnie"

Pomocą w uchwyceniu tego, co dzieci zrozumiały, są ich rysunki, jeśli dziecko wykonuje rysunki tylko opisowe, a nie interpretacyjne, jest to dowód na to, że tekst jest jeszcze za trudny.

Odkrywanie duchowości dziecka pozwala dostrzec Boga z innej perspektywy, z perspektywy dziecka. Bóg widziany oczami dziecka to Bóg Miłości, którą dostrzega w swoim życiu i potrafi się nią radować. Postawa taka wynika z jego naturalnej i życiowej potrzeby. Pozwalając dziecku rozwijać się duchowo, speł-

\footnotetext{
${ }^{36}$ Por. S. Cavalletti, G. Gobbi, Io sono, s. 75.

${ }^{37}$ S. Cavalletti, Potencjat duchowy dziecka, s. 213.

${ }^{38}$ Taż, Formazione religiosa del fanciullo, s. 25.

${ }^{39}$ Taż, Potencjat duchowy dziecka, s. 130.

${ }^{40}$ Tamże, s. 131.
} 
nia się życzenie Jezusa, które zanotował święty Łukasz: „pozwólcie dzieciom przychodzić do Mnie i nie przeszkadzajcie im: do takich bowiem należy królestwo Boże. Zaprawdę powiadam wam: Kto nie przyjmie królestwa Bożego jak dziecko, ten nie wejdzie do niego" (Łk 18, 15-17) ${ }^{41}$. Zdanie to zwraca uwagę na dwa aspekty charakteryzujące dziecięcą duszę, jak zauważa S. Cavalletti: „niewinność i skłonność do wierzenia"42. Do tego można jeszcze dodać radość, która jest owocem spotkania dziecka z Bogiem. A podstawową rolą nauczyciela jest pozwolić dziecku być z Bogiem.

\section{Zakończenie}

Maria Montessori zachęcała wielokrotnie do odkrywania tajemnicy dziecka i roli dzieciństwa w kształtowaniu osobowości człowieka. Wskazywała, że dziecko, które przychodzi na świat, wydaje się bezwładne i bezsilne, wymaga od nas dorosłych troski, opieki, naszej obecności, ale równocześnie, zwracała uwagę, że jest w nim wielka siła życia, która pozwala mu na rozwój wszystkich cech, które odróżniają człowieka od innych stworzeń. Nauczyciel, wychowawca, a przede wszystkim rodzice stoją przed tą wielką tajemnicą życia, darem, jaki został im powierzony. Ich roląjest służyć temu nowemu życiu. Tę siłę życia można porównać do tajemnicy ukrytej w ziarnku gorczycy, które choć wydaje się tak maleńkie, że nie ma na świecie mniejszego ziarnka, ale równocześnie jest w nim tak wielka moc, że wyrasta z niego drzewo. Bóg w całym swoim Objawieniu wciąż kieruje nas ku temu, co proste, małe, słabe, odrzucone przez innych, niedocenione w oczach człowieka dorosłego.

Natomiast wierzący nauczyciel, wychowawca, rodzice dodatkowo stojąprzed drugą wielką Tajemnicą, jaką jest Bóg niepoznawalny, nieograniczony, Bóg, który jest Miłością i do którego ma doprowadzić dziecko. Jest to wielkie i odpowiedzialne zadanie, ale Bóg nie zostawia nas - dorosłych i dzieci - bez odpowiedniej pomocy i wyposażenia w niezbędne narzędzia. Po pierwsze, musimy uwierzyć w to, że w dziecku i w nas działa łaska Boża. Od chwili chrztu świętego jesteśmy wyposażeni w możliwość poznania Boga i nawiązania z Nim relacji. Pierwszym, który tego chce, jest sam Bóg. Wspólnie - dorosły z dzieckiem - pochylając się nad Słowem i uczestnicząc w Liturgii, możemy odkryć żywą Obecność Boga wśród nas i w nas. Rolą dorosłego w formacji religijnej małego dziecka jest doprowadzenie do zażyłości między nimi. Dorosły nie powinien zasłaniać Boga swoją osobą, swoim doświadczeniem, bowiem dziecko żyje w pokojowej relacji z Bogiem, jest Jego niezatartym wizerunkiem.

We współczesnym świecie nie jest łatwo wychowywać dziecko, a jeszcze trudniej jest prowadzić jego formację duchową. Jednak nie jest to niemożliwe.

${ }^{41}$ Teksty paralelne Mt 19, 13-15; Mk 10, 13-16.

${ }^{42}$ S. Cavalletti, Un'avventura: la catechesi del buon Pastore, Rzym 2001, mps, s. 2. 
Jednym z przykładów tak rozumianej formacji jest przedstawiona powyżej propozycja Sofii Cavalletti i Gianny Gobbi.

\section{Religious formation of children and the key role of adults according to the pedagogical concept by Maria Montessori in the example of "The Catechesis of the Good Shepherd" by Sofia Cavalletti} (Summary)

The article raises an important issue of an adult's role in religious formation of a smaller child according to the concept of M. Montessori (1870-1952), which recently has become more and more popular in Poland.

The aim of the thesis is to present the main idea of the "The Catechesis of the Good Shepherd" developed by S. Cavalletti and G. Gobbi. In the first paragraph the general principles of the catechesis are described, conveying the essential biblical message of the Old Covenant between God and a man as a sign of love. In the following paragraph the role of catechesis and a catechist according to Cavalletti is explained in comparison to the Catholic Church's teaching. Finally, the author clears the method of religious teaching by Cavalletti up that tends to be called a "method of signs" in terms of liturgical and biblical language. 